\title{
Desain Penelitian Tindakan Kelas Berbasis Pembelajaran Kooperatif Tipe Teams Game Tournament
}

\section{Sabdah}

\author{
FKIP Universitas Lakidende Konawe
}

email: sabdah.unilaki@gmail.com

\begin{abstract}
Abstrak
Profesionalisme guru tidak hanya ditunjukkan dalam buktibukti formal seperti kepemilikan sertifikat pendidik. Lebih penting lagi adalah pengamalan secara substantif terkait tugas-tugas profesi keguruan. Tuntutan ini menyebabkan guru tidak lagi dapat bertahan pada zona nyaman, hanya menyelenggarakan rutinitas pembelajaran. Pencarian secara terus-menerus terkait pendekatan dan teknik pembelajaran mesti dilakukan, dengan menelusuri literatur-literatur terbaru, juga perkembangan terkini dalam praktik pembelajaran, sehingga dapat menjadi inspirasi terhadap perbaikan pembelajaran di sekolah masing-masing. Penelitian tindakan kelas merupakan salah satu ikhtiar untuk menciptakan tradisi akademik yang baik bagi guru, disamping budaya membaca juga tradisi menulis ilmiah. Sebelum mempratikkan jenis penelitian tindakan, maka guru secara konseptual harus memiliki pemahaman tentang desain penelitian tindakan. Kemampuan menciptakan desain pembelajaran berbasis penelitian tindakan menjadi tanda bahwa guru memiliki kesiapan untuk melakukan perbaikan-perbaikan pembelajaran. Dalam desain pembelajaran menggambarkan alas pikir perlunya tindakan dilakukan, pemahaman terhadap fakta-fakta di kelas, memetakan domain-domain penyelidikan, dan menetapkan strategi pembelajaran yang tepat. Desain juga mensyaratkan penjelasan teknis tentang praktik pembelajaran, mulai dari jenis penelitian, subjek yang diteliti, teknik pengumpulan data, teknik analisis data, dan siklus yang harus dilewati selama pemberian tindakan.
\end{abstract}

Kata Kunci: Desain Penelitian, Pembelajaran Kooperatif 


\title{
Classroom Action Research Design Based on Cooperative Learning Type Teams Game Tournament
}

\section{Sabdah}

FKIP Universitas Lakidende Konawe

email: sabdah.unilaki@gmail.com

\begin{abstract}
Teacher professionalism is not only shown in formal evidence such as ownership of an educator's certificate. More important is the substantive practice related to the duties of the teaching profession. This demand causes the teacher to no longer be able to survive in the comfort zone, only holding learning routines. Continuous search for approaches and learning techniques must be done, by tracing the latest literature, as well as the latest developments in learning practices, so that they can be an inspiration for improving learning in their respective schools. Classroom action research is one of the efforts to create a good academic tradition for teachers, in addition to reading culture as well as the tradition of scientific writing. Before practicing this type of action research, the teacher must conceptually have an understanding of the design of action research. The ability to create action research-based learning designs is a sign that the teacher has readiness to make learning improvements. In the design of learning illustrates the basis for the need for action, understanding the facts in the class, mapping the domains of inquiry, and establishing appropriate learning strategies. Design also requires a technical explanation of learning practices, ranging from the type of research, the subject under study, data collection techniques, data analysis techniques, and cycles that must be passed during the course of action.
\end{abstract}

\section{Keywords: Research Design, Cooperative Learning}




\section{Pendahuluan}

Upaya guru dalam perbaikan praktik pembelajaran dapat dilakukan dengan memberikan tindakan dalam bentuk penerapan model pembelajaran tertentu ${ }^{1}$. Pilihan model pembelajaran tertentu tidak dilakukan begitu saja, tetapi memerhatikan karakteristik dari mata pelajaran sehingga relevan dengan pilihan model pembelajaran. Demikian pula pilihan model pembelajaran merupakan hasil perenungan, juga pembacaan konsep-konsep secara mendalam sehingga seorang peneliti (guru) mendapatkan keyakinan bahwa suatu model pembelajaran adalah solusi jitu atas permasalahan di kelas. Kerangka dasar ini telah mengarahkan kita kepada proses penelitian tindakan kelas ${ }^{2}$.

Penelitian tindakan kelas memiliki alur khas tersendiri, berbeda dengan pendekatan penelitian yang lain ${ }^{3}$. Karenanya seorang peneliti mesti memiliki pemahaman yang baik terkait kebutuhannya menggunakan penelitian tindakan dalam pembelajaran. Pertama, Penelitian tindakan kelas merupakan bentuk penelitian kolaboratif, yang berarti bahwa seorang guru membutuhkan mitra kerja, yang mendampingi selama pelaksanaan tindakan. Tugas mitra kerja ini adalah sebagai pengamat (observer), teman diskusi-reflektif. Kedua, masalah-masalah yang ditemukan di kelas tidak hanya diidentifikasi dan didalami, tetapi lebih penting lagi adalah memberikan solusi yang tepat sehingga masalah teratasi. Ketiga, langkah-langkah penting dalam penelitian yang meliputi perencanaan (planning), tindakan (action), pengamatan (observation), dan refleksi (reflection) mesti dipahami dengan benar. Keempat, keyakinan seorang penelitian tentang babak sisklus yang mesti dilewati sehingga masalah di kelas dapat dipecahkan. Hal ini membutuhkan kecermatan dari peneliti untuk mengenali dengan benar level masalah yang hendak dipecahkan dan kecocokannya dengan model pembelajaran yang ditawarkan. Kelima, pemahaman peneliti tentang aspek-aspek teknis dalam pengumpulan data dan analisis data. Keenam, menyusun kerangka kerja penelitian tindakan yang terintegrasi dengan rencana kegiatan

1 Wibawa, Basuki. "Penelitian Tindakan Kelas." Jakarta: Dirjen Dikdasmen (2003).

${ }^{2}$ Widayati, Ani. "Penelitian tindakan kelas." Jurnal Pendidikan Akuntansi Indonesia 6, no. 1 (2008).

${ }^{3}$ Widayati, Ani. "Penelitian tindakan kelas." Jurnal Pendidikan Akuntansi Indonesia 6, no. 1 (2008). 
pembelajaran. Keenam aspek tersebut selanjutnya disusun menjadi sebuah konsep atau desain penelitian ${ }^{4}$.

Hasil diskusi dengan sesama guru, dan menggali pengalaman mahasiswa ketika mengerjakan usulan penelitian tindakan kelas menunjukkan indikasi bahwa salah satu penyebab terjadi perubahan dalam pembelajaran di kelas disebabkan oleh penegetahuan guru tentang cara memberikan tindakan maupun perlakukan terhadap peserta didik. Salah satunya melalui pelaksanaan penelitian tindakan kelas. Fase awal yang mesti dilakukan oleh seorang peneliti adalah membuat desain penelitian. Artikel ini mencoba memberi ilustrasi mengenai desain penelitian tindakan kelas pada jenjang sekolah dasar.

\section{Domain-Domain Desain Penelitian Tindakan Kelas}

\section{A. Domain Alas Pikir dan Lingkup Kajian}

Domain alas pikir merupakan pijakan dasar perlunya penelitian tindakan kelas dilakukan. Penemuan masalah yang benarbenar layak diteliti mesti dilakukan. Dalam sebuah desain penelitian, alas pikir ini akan berada pada bagian latar belakang masalah, pada bab pendahuluan. Contohnya dapat disajikan sebagai berikut:

\section{Latar Belakang}

\section{Pendahuluan}

Pendidikan merupakan satu aspek yang penting dalam kehidupan setiap individu karena sangat berperan dalam menghasilkan individu yang sehat jasmani dan rohani. Di kehidupan kita, pendidikan tidak hanya yang bersifat formal saja, tetapi mencakup juga yang bersifat informal dan nonformal $^{5}$.

Dalam pendidikan formal, informal, dan nonformal keberhasilan peserta didik ditentukan oleh hasil belajar yang mereka capai selama mengikuti proses pembelajaran. Untuk memperoleh hasil belajar yang maksimal, faktor-faktor

\footnotetext{
${ }^{4}$ Sanjaya, DR H. Wina. Penelitian tindakan kelas. Prenada Media, 2016. Lihat pula

${ }^{5}$ Nasional, Departemen Pendidikan. "Sistem pendidikan nasional." Jakarta (ID): Depdiknas (2003).
} 
pendukung sangat berperan penting untuk menunjang tercapainya tujuan tersebut ${ }^{6}$.

Faktor-faktor tersebut antara lain : motivasi peserta didik dalam mengikuti pelajaran, keaktifan dalam kelas, ketertiban kelas, suasana yang nyaman, penataan inventaris kelas yang sesuai, dan lain sebagainya. Salah satu dari beberapa faktor tersebut yang menjadi perhatian penulis adalah tentang motivasi peserta didik dalam mengikuti pelajaran.

Motivasi dapat diartikan sebagai kekuatan (energi) seseorang yang dapat menimbulkan tingkat antusiasme dalam melaksanakan suatu kegiatan, baik yang bersumber dari dalam diri itu sendiri maupun dati luar individu. Seberapa kuat motivasi yang dimiliki individu akan banyak menentukan terhadap kualitas perilaku yang ditampilkannya, khususnya dalam konteks belajar.

Motivasi belajar siswa sangat penting untuk membantu mencapai tujuan dalam proses pembelajaran. Oleh karena itu, untuk membangkitkan motivasi belajar siswa maka seorang guru dituntut bisa menguasai strategi dan metode dalam mengajar. Hal ini untuk mengantisipasi jika salah satu strategi yang digunakan hasilnya belum maksimal ${ }^{7}$.

Sebagai guru, kita harus memahami bahwa peserta didik yang kita hadapi merupakan pribadi yang unik. Mereka miliki kemampuan yang berbeda-beda, ada yang penangkapannya terhadap pelajaran relatif cepat, ada yang sedang atau biasa saja, mungkin ada juga yang relatif lambat. Dalam pelajaran Pkn misalnya untuk kelas VI SDN Bungguosu, ada siswa yang cepat mengerti dengan apa yang kita sampaikan ada juga yang tidak. ${ }^{8}$ Hal ini akan berakibat terhadap motivasi si anak untuk belajar Pkn, bisa saja si anak jadi enggan untuk belajar. Selain itu, ada juga siswa yang terkadang bosan dengan metode yang sudah sering digunakan

${ }^{6}$ Sudarsana, I. Ketut. "Pemikiran tokoh pendidikan dalam buku lifelong learning: policies, practices, and programs (Perspektif Peningkatan Mutu Pendidikan di Indonesia)." Jurnal Penjaminan Mutu 2, no. 2 (2016): 44-53.

${ }^{7}$ Kontekstual, Pendekatan. "Peningkatan Kemampuan Koneksi Matematis dan motivasi belajar siswa menggunakan pendekatan kontekstual." Jurnal Pendidikan Matematika 1, no. 1 (2019).

${ }^{8}$ Wawancara dengan guru bidang studi Pkn di sd 
sehingga menyebabkan pembelajaran menjadi monoton dan motivasi mereka untuk belajar jadi berkurang.

Salah satu strategi yang dapat kita gunakan untuk menghadapi situasi seperti di atas yaitu Metode TGT (Teams Games Tournament). Metode TGT merupakan salah satu model pembelajaran kooperatif yang mudah dan sangat relevan diterapkan. Relevan karena metode ini melibatkan keaktifan seluruh siswa tanpa adanya perbedaan status dengan mengimplementasikn unsur permainan di dalamnya. Dalam pelaksanaan metode ini, siswa di bagi menjadi 5-6 orang dalam satu kelompok yang heterogen baik secara prestasi, ras, dan jenis kelamin. Selain itu, dalam metode ini ada permainan yang dilakukan. Permainan tersebut merupakan permainan yang sederhana untuk menguji pengalaman yang telah didapat siswa setelah melakukan proses belajar atau diskusi kelompok.

Oleh karena itu, dengan diterapkannya metode TGT diharapkan semua siswa dapat termotivasi untuk belajar, karena dalam metode ini terdapat unsur bermain sambil belajar sehingga membuat siswa tidak bosan dalam proses pembelajaran.

\section{Identifikasi Masalah}

Sebagaimana telah dikemukakan dalam latar belakang serta dari pengamatan awal, dapat diidenfikasikan masalah tersebut sebagai berikut :

1. Proses pembelajaran Pkn kurang kondusif.

2. Metode yang digunakan dalam mata pelajaran Pkn masih metode ceramah.

3. Kurangnya minat siswa untuk belajar Pkn.

4. Belum adanya metode yang tepat.

\section{Rumusan Masalah}

Berdasarkan identifikasi masalah diatas, maka rumusan masalahnya adalah :

1. Apakah dengan penerapan metode Teams Games Tournament (TGT) dapat meningkatkan motivasi belajar siswa kelas VI SDN Bungguosu?

2. Bagaimana penerapan metode Teams Games Tournament (TGT) dalam meningkatkan motivasi belajar siswa? 


\section{Definisi Operasional}

Definisi operasional dalam penelitian ini adalah :

1. Motivasi belajar adalah keseluruhan daya penggerak di dalam diri siswa yang menimbulkan kegiatan belajar, yang menjamin kelangsungan dari kegiatan belajar dan memberikan arah pada KBM, sehingga tujuan yang dikehendaki dapat tercapai.

2. Metode TGT adalah salah satu model pembelajaran kooperatif yang melibatkan keaktifan seluruh siswa tanpa adanya perbedaan dengan mengimplementasikan unsur permainan di dalamnya.

\section{Hipotesis Tindakan}

berikut :

Adapun hipotesis dalam penelitian ini adalah sebagai

"Dengan penerapan metode Team Game Tournament (TGT), dapat meningkatkan motivasi siswa kelas VI SDN Bungguosu pada mata pelajaran PKN."

\section{Tujuan Penelitian}

Tujuan dari penelitian ini adalah sebagai berikut :

1. Meningkatkan kreatifitas guru dalam hal mengembangkan strategi pembelajaran.

2. Meningkatkan motivasi siswa dalam belajar Pkn.

3. Menjadikan proses belajar-mengajar menjadi lebih baik dan menarik.

\section{Manfaat Penelitian}

Penelitian tindakan kelas ini diharapkan memberi manfaat antara lain sebagai berikut:

1. Bagi siswa

Dapat termotivasi dan berperan aktif dalam proses pembelajaran Pkn dengan diterapkannya metode TGT.

2. Bagi guru

Dapat menambah pengetahuan dan kreatifitas guru dalam hal mengembangkan kemampuannya memformulasi strategi pembelajaran agar pembelajaran tersebut tidak monoton.

3. Bagi peneliti 
Dapat menambah pengetahuan dan pengalaman dalam hal penelitian tindakan kelas.

\section{Domain Teoritik : Penguasaan Konsep Pemecahan Masalah Variabel Motivasi}

Secara umum sering orang menyebut kata "motif" untuk menunjuk mengapa seseorang itu berbuat sesuatu. Misalnya, apa motifnya penjahat itu melakukan pencurian atau apa motif si Ali jadi rajin belajar. Dengan demikian, apa yang di maksud dengan motif?

Kata "motif", diartikan sebagai daya upaya yang mendorong seseorang untuk melakukan sesuatu. Motif dapat dikatakan sebagai daya penggerak dari dalam dan di dalam subjek untuk melakukan aktivitas-aktivitas tertentu demi mencapai suatu tujuan. Bahkan motif dapat diartikan sebagai kondisi intern (kesiapsiagaan). Berawal dari kata "motif" itu, maka motivasi dapat diartikan sebagai daya penggerak yang telah menjadi aktif. Motif menjadi aktif pada saat-saat tertentu, terutama bila kebutuhan untuk mencapai tujuan sangat mendesak.

Sebagai contohnya si Ali adalah anak yang malas belajar dan nilainya tidak begitu bagus, sementara ujian semester sisa seminggu lagi. Orang tua Ali pun berkata kepada Ali jika Ali rajin belajar dan bisa memperoleh nilai yang bagus maka dia akan diberi hadiah. Karena perkataan orang tuanya, Ali pun menjadi rajin belajar dan ketika penerimaan raport, Ali memperoleh nilai yang bagus. Dari contoh tersebut, si Ali yang semula malas belajar dan nilai yang diperolehnya tidak begitu bagus, menjadi termotivasi untuk rajin belajar sehingga nilai yang diperolehnya pun bagus karena orang tuanya menjanjikan hadiah. Dengan kata lain, hadiah yang dijanjikan orang tua kepada Ali menjadi daya penggerak Ali untuk rajin belajar.

Motivasi itu ada atau terjadi karena adanya kebutuhan seseorang yang harus segera dipenuhi untuk segera mencapai tujuan. Jika diibaratkan maka motivasi itu sebagai motor penggerak dan bahan bakarnya adalah kebutuhan. Apabila suatu kebutuhan dirasakan mendesak untuk dipenuhi, maka motif dan daya penggerak menjadi aktif. Motif yang telah aktif inilah yang disebut motivasi. 
Motif merupakan tahap awal dari proses motivasi, sehingga motif baru merupakan suatu kondisi intern. Sebab motif tidak selamanya aktif. Motif aktif pada saat tertentu saja, yaitu apabila kebutuhan untuk mencapai tujuan sangat mendesak. Apabila suatu kebutuhan dirasakan mendesak untuk dipenuhi, maka motif dan daya penggerak menjadi aktif.

Motivasi dapat diartikan sebagai kekuatan atau energi seseorang yang dapat menimbulkan tingkat antusiasme dalam melaksanakan suatu kegiatan, baik yang bersumber dari dalam diri individu itu sendiri maupun dari luar individu. Dalam Kamus Besar Bahasa Indonesia (KBBI), motivasi adalah dorongan yang timbul pada diri seseorang sadar atau tidak sadar untuk melakukan suatu tindakan dengan tujuan tertentu ; atau usaha-usaha yang dapat menyebabkan seseorang atau kolompok orang tertentu tergerak melakukan sesuatu karena ingin mencapai tujuan yang dikehendakinya atau mendapat kepuasan dengan perbuatannya 9 .

Selain itu, sebagaimana yang dikutip oleh sardiman dalam bukunya yang berjudul Interaksi dan Motivasi Belajar Mengajar, Mc. Donald juga berpendapat bahwa motivasi adalah perubahan energi dalam diri seseorang yang ditandai dengan muculnya "feeling" dan didahului dengan adanya tanggapan terhadap adanya tujuan. ${ }^{10}$

Untuk memahami motivasi individu dapat dilihat dari beberapa indikator, diantaranya :

1) Durasi kegiatan

2) Frekuensi kegiatan

3) Ketabahan, keuletan, dan kemampuan dalam menghadapi rintangan dan kesulitan

4) Pengorbanan untuk mencapai tujuan

5) Tingkat aspirasi yang hendak dicapai dengan kegiatan yang dilakukan

6) Tingkat kualifikasi prestasi atau produk (out put) yang dicapai dari kegiatan yang dilakukan.

9 Suprihatin, Siti. "Upaya guru dalam meningkatkan motivasi belajar siswa." Jurnal Pendidikan Ekonomi UM Metro 3, no. 1 (2015): 73-82

10 Sardiman. Interaksi dan Motivasi Belajar Mengajar. Jakarta : PT. Rajagrafindo Persada. 2009, h. 73 
7) Arah sikap terhadap sasaran kegiatan. ${ }^{11}$

\section{Hasil Belajar}

Belajar merupakan kegiatan yang paling sering dilakukan orang. Belajar dilakukan dimana saja, kapan saja, dan sedang melakukan apa saja, misalnya di sekolah, di rumah, di jalan, di pasar, sedang bekerja, sedang bermain, malam hari, siang hari, sore hari dan seterusnya. Belajar dapat membawa perubahan bagi si pelaku, baik perubahan pengetahuan, sikap, maupun keterampilan. Dengan perubahan tersebut, membantu orang untuk dapat memecahkan permasalahan dalam hidupnya serta dapat menyesuaikan diri dengan lingkungannya.

Belajar adalah kegiatan yang berproses. Di mana pada proses belajar kemampuan setiap orang yang mengikuti proses tersebut akan diasah. Pada masyarakat awam, pemahaman mereka tentang belajar terbatas pada kegiatan belajar yang dilakukan di lingkungan sekolah saja. Padahal belajar itu bisa terjadi di mana saja, sebagai contoh seseorang bisa saja belajar di lingkungannya tentang bagaimana cara hidup bertetangga atau tentang bagaimana cara bermusyawarah dan lain sebagainya. Di tempat kursus pun misalnya kursus matematika, hal itu merupakan belajar meskipun tempatnya agak berbeda dengan suasana di sekolah ${ }^{12}$.

Belajar adalah suatu proses usaha yang dilakukan individu untuk memperoleh suatu perubahan tingkah laku yang baru secara keseluruhan, sebagai hasil pengalaman individu itu sendiri dalam interaksi dengan lingkungannya. ${ }^{13}$ Belajar juga adalah "Learning may be defined as the process by which behavior originates or is a altered through training or experience. (belajar sebagai proses ketika tingkah laku ditimbulkan atau diubah melalui latihan atau pengalaman). ${ }^{14}$

11 Ratna Yudhawati dan dany haryanto. Teori-Teori Dasar Psikologi Pendidikan. Jakarta : PT. Prestasi Pustakaraya. 2011, h. 79

12 Winataputra, Udin Saripudin, Refny Delfi, Paulina Pannen, and Dina Mustafa. "Teori belajar dan pembelajaran." (2014): 1-46. 2011 , h. 102

${ }^{13}$ Syaiful Bahri Djamarah. Psikologi Belajar. Jakarta : Pt. Rineka Cipta.

${ }^{14}$ Baharuddin. Pendidikan Dan Psikologi Perkembangan. Yogyakarta : ArRuzz Media. 2010 h. 163 
Dapat di simpulkan bahwa belajar adalah proses yang dilakukan seseorang untuk memperoleh perubahan tingkah laku, keahlian, tambahan pengetahuan melalui latihan dan pengalaman yang didapatnya selama proses belajar. Dengan kata lain, maka dengan belajar seseorang akan mengalami perubahan tingkah laku, memperoleh keahlian, memperoleh tambahan pengetahuan yang nantinya akan sangat berguna untuk kehidupannya. Hal-hal pokok dalam belajar yaitu sebagai berikut :

1) Perubahan dengan kecakapan yang baru.

2) Latihan atau praktek tersebut terjadi karena adanya usaha.

3) Perubahan tingkah laku aktual maupun potensial.

\section{Motivasi Belajar}

Dalam kegiatan belajar mengajar, apabila seorang siswa tidak berbuat sesuatu yang seharusnya dikerjakannya, maka perlu diselidiki apa sebabnya. Sebab-sebab itu biasanya bermacam-macam, mungkin ia mengantuk, lapar, bosan dengan metode mengajar guru yang monoton, atau problem pribadi lainnya. Keadaan semacam ini perlu dicarikan solusinya, agar dapat mrndorong siswa melakukan sesuatu yang seharusnya dilakukannya yakni mengikuti pelajaran dengan baik. Dengan kata lain, siswa tersebut harus diberikan rangsangan agar tumbuh motivasi pada dirinya.

Dalam kegiatan belajar, motivasi dapat dikatakan sebagai keseluruhan daya penggerak di dalam diri siswa yang menimbulkan kegiatan belajar, yang menjamin kelangsungan dari kegiatan belajar dan yang memberikan arah pada kegiatan belajar, sehingga tujuan yang dikehendaki oleh subjek belajar itu dapat tercapai.

Motivasi belajar merupakan faktor psikis yang bersifat non-intelektual. Peranannya yang khas adalah dalam menumbuhkan gairah belajar siswa agar merasa senang dan semangat untuk belajar. Siswa yang memiliki motivasi yang kuat, akan mempunyai banyak energi untuk kegiatan pembelajaran. Seorang siswa yang memiliki intelegensi yang cukup tinggi, boleh jadi gagal karena kekurangan motivasi. Hasil belajar akan optimal jika ada motivasi yang tepat. Kegagalan yang terjadi itu jangan dilimpahkan semua 
kesalahannya pada pihak siswa, sebab mungkin saja guru tidak berhasil dalam memberi motivasi yang mampu membangkitkan semangat dan kegiatan siswa untuk belajar. Jadi tugas guru bagaimana mendorong para siswa agar pada dirinya tumbuh motivasi ${ }^{15}$.

Penting untuk diketahui oleh siswa bahwa motivasi belajar dapat ditumbuhkan dan dikembangkan dari dalam diri siswa itu sendiri melalui pemmahaman akan tujuan, kebutuhan, dan perasaan diri. Siswa yang merasa bahwa ilmu pengetahuan itu sangat penting dan brmanfaat bagi kehidupan, maka dalam dirinya akan muncul sikap berprestasi, sebaliknya siswa yang tidak memahami hal tersebut akan mengalami kejenuhan dalam belajar.

Oleh karena itu, dalam belajar sangat diperlukan adanya motivasi. Hasil belajar akan menjadi optimal kalau ada motivasi. Makin tepat motivasi yang diberikan, akan makin berhasil pula pelajaran itu dilaksanakan. Motivasi akan senantiasa menentukan intensitas usaha belajar bagi para siswa dan akan sangat menentukan tingkat pencapaian prestasi belajarnya.

\section{Metode TGT (teams games tournament)}

Syarat-syarat yang harus diperhatikan seorang guru dalam penggunaan metode pembelajaran adalah sebagai berikut :

1) Metode yang dipergunakan harus dapat membangkitkan motivasi, minat, atau gairah belajar siswa.

2) Metode yang digunakan dapat merangsang keinginan siswa untuk belajar lebih lanjut, seperti melakukan inovasi dan ekspotasi.

3) Metode yang digunakan harus dapat memberikan kesempatan pada siswa untuk mewujudkan hasil karyanya.

15 Kiswoyowati, Amin. "Pengaruh motivasi belajar dan kegiatan belajar siswa terhadap kecakapan hidup siswa." Portal Jurnal Universitas Pendidikan Indonesia 2, no. 1 (2011): 12-16. 
4) Metode yang digunakan harus dapat menjamin perkembangan kegiatan kepribadian siswa ${ }^{16}$.

5) Metode yang digunakan harus dapat mendidik siswa dalam teknik belajar sendiri dan cara memperoleh pengetahuan melalui usaha pribadi.

6) Metode yang digunakan harus dapat menanamkan dan mengembangkan nilai-nilai dan sikap siswa dalam kehidupan sehari-hari. ${ }^{17}$

Metode pembelajaran teams games tournament disingkat TGT merupakan salah satu model pembelajaran kooperatif yang pada mulanya dikembangkan oleh David Devries dan Keith Edwards, ini merupakan metode pembelajaran pertama dari Johns Hopkins. Dalam metode ini, para siswa dibagi dalam tim belajar yang terdiri atas empat sampai lima orang yang berbeda-beda tingkat kemampuan, jenis kelamin, dan latar belakang etniknya. Guru menyampaikan pelajaran, lalu siswa bekerja dalam tim mereka untuk memastikan bahwa semua anggota tim telah menguasai pelajaran. Selanjutnya diadakan turnamen, di mana siswa memainkan game akademik dengan anggota tim lain untuk menyumbangkan poin bagi skor timnya. TGT menambahkan dimensi kegembiraan yang diperoleh dari penggunaan permainan. Teman satu tim akan saling membantu dalam mempersiapkan diri untuk permainan dengan mempelajari lembar kegiatan dan menjelaskan masalah-masalah satu sama lain, memastikan telah terjadi tanggung jawab individual ${ }^{18}$.

Pendapat lain mengemukakan bahwa pembelajaran kooperatif tipe TGT adalah salah satu metode pembelajaran kooperatif yang mudah diterapkan, melibatkan aktivitas seluruh siswa tanpa harus ada perbedaan status, melibatkan peran siswa sebagai tutor sebaya dan mengandung unsur

${ }^{16}$ Fathurrohman, Muhammad. "Model-Model Pembelajaran." Universitas Negeri Yogyakarta. Jogjakarta: Ar-Ruzz Media. Retrieved from (2015).

${ }^{17}$ Ahmad sabri. Strategi Belajar Mengajar Dan Micro Teaching. Ciputat : Quantum Teaching. 2007, h. 127

18 Purnamasari, Yanti. "Pengaruh Model Pembelajaran Kooperatif Tipe Teams Games-Tournament (TGT) Terhadap Kemandirian Belajar Dan Peningkatan Kemampuan Penalaran Dan Koneksi Matematik Peserta Didik SMPN 1 Kota Tasikmalaya." PhD diss., Universitas Terbuka, 2013. 
permainan dan reinforcement. Aktivitas belajar dengan permainan yang dirancang dalam pembelajaran kooperatif tipe TGT memungkinkan siswa dapat belajar lebih rileks disamping menumbuhkan tanggung jawab, kerja sama, persaingan sehat dan keterlibatan belajar. ${ }^{19}$

Metode Teams Game Tournament (TGT) merupakan metode yang menyenangkan karena menggabungkan permainan di dalamnya sehingga peserta didik merasa senang dan tidak jenuh belajar. Ada beberapa komponen dalam metode Teams Games Tournament ini, yaitu sebagai berikut :

1) Presentasi Di kelas

Materi dalam TGT pertama-tama diperkenalkan dalam presentasi dalam kelas. Hal ini merupakan pengajaran langsung yang dipimpin oleh guru. Dengan cara ini siswa akan menyadari bahwa mereka harus memperhatikan apa yang disampaikan oleh guru, karena dengan demikian akan sangat membantu mereka dalam melaksanakan permainan dalam metode TGT.

2) $\mathrm{Tim}$

Tim terdiri dari empat atau lima siswa yang heterogen yang dilihat dari jenis kelamin, kemampuan akdemik, ras dan etnis. Fungsi utama dari tim adalah memastikan bahwa semua anggota tim benar-benar belajar, dan lebih khususnya lagi adalah untuk mempersiapkan anggotanya untuk bisa melakukan permainan dengan baik.

3) Game

Gamenya terdiri atas pertanyaan-pertanyaan yang kontennya relevan yang dirancang untuk menguji pengetahuan yang diperolehnya dari presentasi kelas dan pelaksanaan kerja tim. Game tersebut dimainkan di atas meja dengan tiga orang siswa yang yang mewakili tim yang berbeda kebenyakan game hanya berupa nomor-nomor pertanyaan yang ditulis pada lembar yang sama. Seorang siswa mengambil sebuah kartu bernomor dan harus menjawab pertanyaan sesuai nomor yang tertera pada kartu

19 Agus Susilo H. Teams Games Tournament (online) (http://aguseducated.wordpress.com, diakses 17 November 2012) 2012 
tersebut. Sebuah aturan tentang penantang memperbolehkan para pemain saling menantang jawaban masing-masing.

4) Turnamen

Turnamen adalah sebuah struktur di mana game berlangsung. Biasanya berlangsung pada akhir minggu atau akhir unit, setelah guru meberikan presentasi di kelas dan tim telah melaksanakan kerja kelompok terhadap lembar kagiatan

5) Rekognisi Tim

Tim akan mendapat sertifikat atau bentuk penghargaan yang lain apabila skor rata-rata mereka mencapai kriteria tertentu.

Slavin menyebutkan jadwal kegiatan dalam

pelaksanaan metode TGT terdiri dari empat kegiatan yaitu sebagai berikut :

1) Pengajaran, sebelum memulai permainan guru harus memberikan pelajaran yang terkait dengan materi.

2) Belajar tim, di sini para siswa mengerjakan lembar kegiatan dalam tim mereka untuk menguasai materi.

3) Turnamen, para siswa memainkan game akademik dalam kemampuan yang homogen, dengan meja turnamen tiga peserta.

4) Rekognisi tim, skor tim dihitung berdasarkan skor turnamen anggota tim, dan tim tersebut akan direkognisi apabila mereka berhasil melampaui kriteria yang telah ditetapkan ${ }^{20}$.

Adapun prosedur pelaksanaan permainan dalam bentuk turnamen metode TGT adalah sebagai berikut :

1) Guru menentukan nomor urut siswa dan menempatkan siswa pada meja turnamen (3 orang dan kemampuan yang setara). Setiap meja terdapat 1 lembar permainan, 1 lembar jawaban, 1 kotak kartu nomor, 1 lembar skor permainan.

2) Siswa mencabut kartu untuk menentukan pembaca I (nomor tertinggi) dan yang lain menjadi penantang I dan II.

3) Pembaca I menggocok kartu dan mengambil kartu yang teratas.

4) Pembaca I membaca soal sesuai nomor pada kartu dan mencoba menjawabnya. Jika jawaban salah, tidak ada

${ }^{20}$ Slavin, Robert E. "Cooperative learning." Review of educational research 50, no. 2 (1980): 315-342. 
sanksi dan kartu dikembalikan. Jika benar kartu disimpan sebagai bukti skor.

5) Jika penantang I dan II memiliki jawaban berbeda, mereka dapat mengajukan jawaban secara bergantian.

6) Jika jawaban penantang salah, dia dikenakan denda mengembalikan kartu jawaban yang benar (jika ada).

7) Selanjutnya siswa berganti posisi (sesuai urutan) dengan prosedur yang sama.

8) Setelah selesai, siswa menghitung kartu dan skor mereka dan diakumulasi dengan semua tim.

9) Penghargaan sertifikat, Tim Super untuk kriteria atas, Tim Sangat Baik (kriteria tengah), Tim Baik (kriteria bawah).

10) Untuk melanjutkan turnamen, guru dapat melakukan pergeseran tempat siswa berdasarkan prestasi pada meja turnamen $^{21}$.

Metode TGT ini merupakan salah satu dari sekian banyak metode yang digunakan untuk mencapai tujuan dari pembelajaran itu sendiri. Seperti halnya metode yang lain, metode TGT ini mempunyai kelebihan sebagai berikut:

- Model TGT tidak hanya membuat sisws yang cerdas (berkemampuan akadimis tinggi) lebih menonjol dalam pembelajaran, tetapi siswa yang berkemampuan akademi lebih rendah juga ikut aktif dan mempunyai peranan yang penting dalam kelompoknya.

- Dengan metode ini, akan menumbuhkan rasa kebersamaan dan saling menghargai sesama anggota kelompoknya.

- Dalam metode ini, membuat siswa lebih bersemangat dalam mengikuti pelajaran. Karena dalam metode ini, guru menjanjikan sebuah penghargaan pada siswa atau kelompok terbaik.

- Dalam metode siswa ini membuat siswa menjadi lebih senang dalam mengikuti pelajaran karena ada kegiatan permainan berupa tournamen dalam metode ini.

21 Saputra, Fendy, Siti Roudlotul Hikamah, and Minahur Rohman. "Penerapan Pembelajaran Kooperatif Tipe Tgt (Team Games Tournament) Dengan Media Kokami Dalam Meningkatkan Hasil Belajar Biologi." Jurnal Bioshell 2, no. 1 (2013). 
berikut:

Adapun kekurangan metode TGT adalah sebagai

- Dalam metode ini, harus menggunakan waktu yang sangat lama.

- Dalam metode ini, guru dituntut untuk pandai memilih materi pelajaran yang cocok untuk model ini.

- Guru harus mempersiapkan metode ini dengan baik sebelum diterapkan. Misalnya membuat soal untuk setiap meja turnamen atau lomba, dan guru harus tahu urutan akademis siswa dari yang tertinggi hingga terendah ${ }^{22}$.

\section{Kerangka Pikir}

Dalam penelitian ini penulis ingin membuktikan bahwa penerapan metode TGT (teams games tournament) mempunyai pengaruh positif terhadap motivasi belajar siswa pada mata pelajaran Pkn. Pembelajaran Pkn hendaknya didesaian dengan metode yang dapat menarik minat siswa untuk belajar Pkn. Dengan metode yang biasa-biasa saja tentunya siswa akan merasa bosan sehingga motivasi mereka untuk belajar Pkn menjadi berkuramg atau bahkan tidak ada sama sekali. Dengan diterapkannya metode TGT (teams games tournament) diharapkan siswa dapat termotivasi untuk belajar Pkn, karena dalam metode ini mengkolaborasikan antara permainan, turnamen, dan kerjasama tim.

\section{Penelitian Relevan}

Adapun penelitian yang relevan dengan penelitian ini adalah penelitian yang dilakukan oleh saudara La Yamin dengan judul "Peningkatan Motivasi Belajar pendidikan kewarganegaraan Melalui Pendekatan Cooperative Learning Tipe Numbered Heads Together (NHT) Siswa Kelas VI Kec. Baruga Kota kendari”. Berdasarkan hasil observasi dan evaluasi pada tiap-tiap siklus kenyataan dapat disimpulkan bahwa melalui penerapan pembelajaran cooperative tipe NHT di kelas Kelas VI Kec. Baruga Kota kendari semester genap

${ }^{22}$ Solihah, Ai. "Pengaruh Model Pembelajaran Teams Games Tournament (TGT) terhadap Hasil Belajar Matematika." SAP (Susunan Artikel Pendidikan) 1, no. 1 (2016). 
tahun ajaran 2017/2018, bahwa motivasi belajar siswa dapat ditingkatkan. Hal ini dapat dilihat dari hasil evaluasi sebelum diberikan tindakan dan setelah diberikan tindakan siklus I dan siklus II dimana nilai rata-rata yang diperoleh mengalami peningkatan yaitu dari 71,2 menjadi 77,2 sebesar $64 \%$ secara klasikal, namun pencapaian ini belum mencapai indikator kinerja yang ditetapkan yaitu $80 \%$ atau siswa memperoleh nilai 75. Selanjutnya pada siklus II nilai rata-rata siswa meningkat menjadi $82.8 \%$ atau $92 \%$ secara klasikal. Dan ini telah memenuhi indikator kinerja yang telah ditetapka yaitu $80 \%$ atau siswa memperoleh nilai 75 , dengan perolehan ini maka pelaksanaan tindakan dihentikan karena telah mencapai indikator kerja yang telah ditetapkan.

\section{Domain Metodologi Riset: Kerangka Teknis Pemecahan Masalah}

\section{Jenis Penelitian}

Penelitian ini termasuk penelitian tindakan kelas (PTK), karena penelitian ini dilakukan untuk memecahkan pembelajaran di kelas. Penelitian Tindakan Kelas (PTK) adalah bentuk penelitian yang tidak formal, yakni penelitian yang bersifat longgar dalam menerapkan prinsip-prinsip metode ilmiah, oleh karena tujuan utamanya bukan menemukan atau menggeneralisasi akan tetapi memperbaiki proses pembelajaran. Dengan demikian, baik dalam proses pengumpulan data, menganalisis data, sampai pada proses pengambilan kesimpulan sangat situasional sesuai dengan keadaan tertentu yang bersifat subjektif.

\section{Waktu Dan Tempat Penelitian}

Penelitian ini dilakukan pada semester genap tahun pelajaran 2017/2018 di SDN Bungguosu. Waktu penelitian direncanakan selama 2 bulan.

\section{Subjek Penelitian}

Adapun subjek dalam penelitian ini adalah kelas VIb yang terdiri dari 37 siwa-siswi di SDN Bungguosu 


\section{Faktor Yang Diteliti}

Untuk lebih memudahkan dalam pemecahan masalah, ada beberapa hal yan akan diteliti antara lain :

- Faktor siswa, yaitu dilakukan pemantauan dengan memperhatikan perkembangan motivasi belajar siswa dalam mata pelajaran Pkn dengan menggunakan metode Team Game Tournament (TGT).

- Faktor guru, yaitu melihat aktivitas guru meliputi kesiapan guru dalam melaksanakan kegiatan pembelajaran, mengorganisir siswa dalam menerapkan metode TGT.

- Faktor proses pembelajaran, yaitu dengan melihat proses pembelajaran dengan metode TGT sudah sesuai dengan prosedur untuk mencapai tujuan yang diinginkan.

\section{Prosedur Penelitian}

Penelitian Tindakan Kelas (PTK) ini pelaksanaanya sebanyak dua siklus. Setiap siklus terdiri dari beberapa tahapan kegiatan, yaitu : 1) perencanaan; 2) aksi atau tindakan; 3) observasi; 4) refleksi. Secara garis besar setiap tahapan kegiatan dijelaskan sebagai berikut :

1. Perencanaan

a. Membuat skenario pembelajaran yang berisi langkahlangkah dan bentuk-bentuk kegiatan yang akan dilakukan.

b. Mempersiapkan fasilitas dan sarana pendukung yang diperlukan di kelas.

c. Mempersiapkan instrumen pengamatan.

d. Mengembangkan skenario pembelajaran TGT.

2. Aksi atau tindakan
a. Guru memberikan motivasi kepada siswa dan mengarahkan siswa memasuki materi yang akan dibahas.
b. Guru menjelaskan tujuan pembelajaran yang akan dicapai.
c. Guru menjelaskan materi dan menjelaskan langkah- langkah pelaksanaan metode TGT.
d. Guru membagi siswa ke dalam beberapa kelompok, setiap kelompok terdiri dari lima sampai enam siswa.


e. Guru melaksanakan pembelajaran sesuai dengan skenario yang telah direncanakan.

3. Observasi

Pada tahap ini, peneliti melakukan pengamatan terhadap proses dan hasil dari pelaksanaan kegiatan. Kegiatan observasi ini dilakukan untuk mengumpulkan informasi tentang proses pembelajaran yang dilakukan guru sesuai dengan tindakan yang telah disusun. Melalui pengumpulan informasi, observer dapat mencatat berbagai kelemahan dan kekuatan yang dilakukan guru dalam melaksanakan tindakan, sehingga hasilnya dapat dijadikan masukan ketika guru melakukan refleksi untuk penyusunan rencana ulang memasuki siklus berikutnya.

4. Refleksi

Tahapan ini dimaksudkan untuk mengkaji secara menyeluruh tindakan yang telah dilakukan, berdasarkan data yang telah terkumpul, kemudian dilakukan evaluasi guna menyempurnakan tindakan berikutnya.

\section{Teknik Pengumpulan Data}

Teknik pengumpulan data adalah sebagai berikut :

a. Observasi, meliputi pengamatan terhadap aktivitas guru dalam menerapkan metode TGT dan aktivitas kegiatan siswa dalam melakukan kegiatan belajar-mengajar.

b. Tes formatif, tes yang dilakukan guru setiap akhir siklus kegiatan pembelajaran, tes ini dilakukan untuk mengetahuihasil belajar yang dicapai sisqa pada setiap akhir kegiatan pembelajaran, yang secara otomatis motivasi belajarnya juga meningkat jika hasilnya baik.

c. Dokumentasi dilakukan dalam bentuk perekaman kegiatan pembelajaran dan pembacaan nilai-nilai ujian sebelum pemberian tindakan.

d. wawancara dilakukan untuk mendalami persoalan-persoalan yang belum terdalami dalam lembar observasi.

\section{Teknik Analisis Data}

Data dalam penelitian ini dianalisis dengan menggunakan analisis deskriptif untuk memberikan gambaran motivasi belajar siswa dalam pelajaran Pkn yang diajarkan 
dengan menggunakan metode Teams Games Tournament (TGT).

Adapun langkah-langkah analisis sebagai berikut :

1. Guru melihat dan mengamati penerapan metode Teams Games Tournament (TGT) dalam proses pembelajaran.

2. Motivasi siswa dalam PBM, menganalisis berdasarkan beberapa indikator yang telah ditentukan.

Dalam Penelitian Tindakan Kelas, ada dua jenis data yang dapat dikumpulkan peneliti, yaitu :

1. Data kuantitatif, (nilai hasil belajar) yang dapat dianalisis secara deskriptif. Dalam hal ini peneliti menggunakan analisis statistik deskriptif. Misalnya, mencari nilai ratarata, persentase keberhasilan belajar, dan lain-lain.

Adapun rumus-rumus yang digunakan adalah :

1) Penskoran hasil tes

Rentang skor yang digunakan untuk tes obyektif dalam penelitian ini adalah 0 sampai dengan 100, maka penskoran dilakukan dengan pembobotaan, rumusnya yaitu :

$$
\text { skor }=\frac{\text { jumlah jawaban yury benar }}{\text { jumlah sual }} \times 100
$$

2) Menentukan nilai rata-rata

$$
\begin{aligned}
\bar{X}=\frac{\sum X_{1}}{N} & \\
\text { Ket }: \quad \bar{X} & =\text { nilai rata }- \text { rata } \\
X_{1}= & \text { skor tiap }- \text { tiap siswu } \\
& \quad \mathrm{N}=\text { jumlah siswa }
\end{aligned}
$$

3) Menentukan ketuntasan belajar

$$
\begin{gathered}
\% \text { tuntas }=\frac{\sum T b^{\prime}}{N} \times 100 \% \\
\text { Ket : } \sum T B^{\prime}=\text { jumlah siswa yang tuntas belajar } \\
\mathrm{N}=\text { jumlah siswa secara keseluruhan }
\end{gathered}
$$

2. Data kualitatif yaitu data yang berupa informasi berbentuk kalimat yang memberi gambaran tentang ekspresi siswa tentang tingkat pemahaman terhadap suatu mata pelajaran (kognitif), 
pandangan atau sikap siswa terhadap metode belajar yang baru (efektif), aktivitas siswa mengikuti pelajaran, perhatian, antusias dalam belajar, kepercayaan diri, motivasi belajar, dan sejenisanya dapat dianalisis secara kualitatif.

\section{Indikator Kinerja}

Sebagai standar keberhasilan penelitian ini adalah meningkatnya motivasi belajar siswa sebesar $80 \%$ yang ditandai dengan melaksanakan indikator yang diobservasi dalam lembar observasi kegiatan siswa selama proses kerja kelompok dan ketuntasan belajar mencapai $80 \%$ pada mata pelajaran Pkn kelas VI di SDN Bungguosu.

\section{Kesimpulan}

Desain penelitian dapat juga disebut sebagai usulan penelitian, yang di dalamnya mencakup domain alas pikir yang menandai pentingnya penelitian tindakan dilakukan. Selanjutnya penguatan konseptual, yaitu penelusuran konseptual tentang solusi yang ditawarkan agar memiliki kekuatan teoritik yang memadai. Bagian terakhir adalah teknis pelaksanaan tindakan, yang berintikan pemahaman teknis tentang pelaksanaan penelitian tindakan kelas. 


\section{Daftar Pustaka}

Baharuddin. Pendidikan Dan Psikologi Perkembangan. Yogyakarta : Ar-Ruzz Media. 2010

Djamarah, Syaiful Bahri, Psikologi Belajar. Jakarta : Pt. Rineka Cipta. 2011.

Fathurrohman, Muhammad. "Model-Model Pembelajaran." Universitas Negeri Yogyakarta. Jogjakarta: Ar-Ruzz Media. Retrieved from (2015).

Kontekstual, Pendekatan. "Peningkatan Kemampuan Koneksi Matematis dan motivasi belajar siswa menggunakan pendekatan kontekstual." Jurnal Pendidikan Matematika 1, no. 1 (2019)

Kiswoyowati, Amin. "Pengaruh motivasi belajar dan kegiatan belajar siswa terhadap kecakapan hidup siswa." Portal Jurnal Universitas Pendidikan Indonesia 2, no. 1 (2011)

Nasional, Departemen Pendidikan. "Sistem pendidikan nasional." Jakarta (ID): Depdiknas (2003)

Purnamasari, Yanti. "Pengaruh Model Pembelajaran Kooperatif Tipe Teams Games-Tournament (TGT) Terhadap Kemandirian Belajar Dan Peningkatan Kemampuan Penalaran Dan Koneksi Matematik Peserta Didik SMPN 1 Kota Tasikmalaya." PhD diss., Universitas Terbuka, 2013.

Ratna Yudhawati dan dany haryanto. Teori-Teori Dasar Psikologi Pendidikan. Jakarta : PT. Prestasi Pustakaraya. 2011

Sabri, Ahmad, Strategi Belajar Mengajar Dan Micro Teaching. Ciputat: Quantum Teaching. 2007.

Sanjaya, DR H. Wina. Penelitian tindakan kelas. Prenada Media, 2016.

Saputra, Fendy, Siti Roudlotul Hikamah, and Minahur Rohman. "Penerapan Pembelajaran Kooperatif Tipe Tgt (Team Games Tournament) Dengan Media Kokami Dalam Meningkatkan Hasil Belajar Biologi." Jurnal Bioshell 2, no. 1 (2013).

Sardiman. Interaksi dan Motivasi Belajar Mengajar. Jakarta : PT. Rajagrafindo Persada. 2009

Slavin, Robert E. "Cooperative learning." Review of educational research 50, no. 2 (1980) 
Solihah, Ai. "Pengaruh Model Pembelajaran Teams Games Tournament (TGT) terhadap Hasil Belajar Matematika." SAP (Susunan Artikel Pendidikan) 1, no. 1 (2016)

Sudarsana, I. Ketut. "Pemikiran tokoh pendidikan dalam buku lifelong learning: policies, practices, and programs (Perspektif Peningkatan Mutu Pendidikan di Indonesia)." Jurnal Penjaminan Mutu 2, no. 2 (2016)

Suprihatin, Siti. "Upaya guru dalam meningkatkan motivasi belajar siswa." Jurnal Pendidikan Ekonomi UM Metro 3, no. 1 (2015)

Agus Susilo H. Teams Games Tournament (online) (http://aguseducated.wordpress.com, diakses 17 November 2012)

Wibawa, Basuki. "Penelitian Tindakan Kelas." Jakarta: Dirjen Dikdasmen (2003).

Widayati, Ani. "Penelitian tindakan kelas." Jurnal Pendidikan Akuntansi Indonesia 6, no. 1 (2008)

Winataputra, Udin Saripudin, Refny Delfi, Paulina Pannen, and Dina Mustafa. "Teori belajar dan pembelajaran." (2014) 